\title{
The Effect of Citrus Limon and Whitening Toothpaste to Teeth Color Changes (Study on the Right Maxillary Central Incisor of 18 Year Old Female)
}

\author{
Octarina \\ Department of Dental Material \\ Faculty of Dentistry, Trisakti University \\ Jakarta, Indonesia
}

\author{
Elfira Aprilianti \\ Student \\ Faculty of Dentistry, Trisakti University \\ Jakarta, Indonesia
}

\begin{abstract}
The acids of Citrus limon is believed to be able to brighten teeth, meanwhile whitening toothpaste is able to remove stain of the teeth. The purpose of this study was to observe the effect of Citrus limon water and whitening toothpaste to teeth color changes. Fifteen female students of Dentistry Faculty of Trisakti University, participated in this study (ethical clearance). The color of right maxillary central incisor of those participant was measured by spectrophotometer (VITA Easyshade V, USA) for 3 weeks respectively. The color measurement was divided into 4 treatments: before treatment; brushed with whitening toothpaste for 28 minutes +42 drops of Citrus limon; brushed with whitening toothpaste for 56 minutes +84 drops of Citrus limon; brushed with whitening toothpaste for 84 minutes +126 drops of Citrus limon. The results of color change are: $\Delta \mathrm{E} 1(+1.4 \pm 1.3)$, $\Delta E 2(+1.2 \pm 1.3), \Delta E 3(+1.6 \pm 1.5)$. Results of lightness are $\Delta \mathrm{L} 1(+1.2 \pm 1.8), \Delta \mathrm{L} 2(+0.580 \pm 2.1), \Delta \mathrm{L3}(+0.7 \pm 2.0)$. Results of chroma are $\Delta \mathrm{C} 1(+1.0 \pm 1.3), \Delta \mathrm{C} 2(+0.7 \pm 1.2)$, $\Delta C 3(+1.1 \pm 1.8)$. Results of hue are $\Delta H 1(-0.7 \pm 0.9), \Delta H 2$ $(-0.4 \pm 1.7), \Delta H 3(0.2 \pm 1.9)$. The data were analyzed with repeated anova. In this study, the total measurement of color change was showed by decreasing value of $\Delta \mathrm{E}$. The color of their teeth get brighter during the 3 weeks application. Statistical tests show significant differences of $\Delta E(p<0.05)$. The malic acid in Citrus limon and abrasive ingredients in whitening toothpaste are able to brighten the color of their teeth.
\end{abstract}

Keywords-Citrus limon, whitening toothpaste, color change

\section{INTRODUCTION}

Teeth look "brighter and white" is one of the most common types of dental care. Treatment by using a whitening toothpaste, can make tooth looked bright. Whitening toothpaste that is used widely in our community contains abrasives. It is used because it can remove plaque and stains of the teeth, so the teeth looked brighter [1].

Besides using a whitening toothpaste, we can also use natural ingredients for brightening teeth. One of natural ingredients that is found in fruits, that has the ability to brighten the color of teeth is malic acid [2]. Malic acid is a dicarboxylic which has the ability to whiten teeth by oxidizing the surface of the tooth enamel. One of fruit that contains malic acid is lemon (Citrus limon). Lemon is a tropical fruit that is easily found in Indonesia. Lemon can remove stain on the tooth surface. The acidity of the lemon fruit is at $\mathrm{pH} \mathrm{2-3}$ which is very acid and it is below the critical $\mathrm{pH}$ of enamel ( $\mathrm{pH}$ 5,5). This acidic nature leads to demineralization, so the teeth become whiter [3].

The color in dentistry is very important and commonly measured in reflected light using a color measuring instrument or a visual method. We use the munsell color system that is used in dentistry as color measuring guidence. This system uses a threedimensional system with hue, value, and chroma. Hue is commonly referred to color; examples, yellow, red and blue. Hue is also associated with the wavelengths of the light observed. Value in this dimensional system is the lightness or darkness of a color. A tooth of low value, appears gray and nonvital. Value is the most important color factor in tooth color matching. Chroma is a measurement of color intensity; that is, the amount of hue saturation in a color $[4,5]$.

According to Glossary of Prosthodotics, "Shade" is used to describe the hue or variation of primary hue. Tools determining the color of the tooth is called shade guide.Vitapan classic and vita 3D-master are some of shade guide that we found in commercial [6]. To measure the color of teeth, we can use color measuring instruments i.e spectrophotometers and colourimeters. Spectrophotometer give more advantages than colourimeters. Colourimeters can only observed at three wavelengths of colors, i.e. red, green, and blue. Meanwhile the spectrophotometer can measure the whole spectrum of colors. One type of spectometer is VITA easyshade. VITA easyshade is a tool for measuring the overall color of the teeth. This tool is able to defferentiate the area of the cervical, middle and incisal of teeth, it is also able to determines color of the restoration [7].

The surface of the anterior teeth is a visible part of the smile. Having a smile by white teeth can impress a positive image and self-confidence. Therefore, this 
study wanted to know "The effect of Citrus limon and whitening toothpaste to teeth color changes".

\section{MATERIALS AND METHODS}

A total of 15 students from the Faculty of Dentistry, Trisakti University, 18 years old were participated in this research. The participant requirement in this study were a right maxillary central incisor (11), carries free, without restoration and orthodontic use. Tooth color measurements were performed before application, first week, second week and third week after application with Citrus limon and whitening toothpaste. Each time color measure on the tooth, the participants do tooth brushing without toothpaste. The color measurement were using spectrophotometer (Vita Easyshade V, USA) that is placed on the middle surface of the tooth 11 and repeat three times.

TABLE I. COMPOSITION AND ORIGIN OF MATERIALS IN THE STUDY

\begin{tabular}{|c|c|l|l|}
\hline No & Material & \multicolumn{1}{|c|}{ Composition } & Origin of Materials \\
\hline 1. & $\begin{array}{c}\text { Lemon } \\
\text { water }\end{array}$ & $\begin{array}{l}\text { Citric acid, ascorbic acid } \\
\text { (vitamin C), vitamin B6, } \\
\text { vitamin A, vitamin eglucaric } \\
\text { acid, folate, thiamin niacin, } \\
\text { riboflavin, pantothenic acid, } \\
\text { and polyphenols }\end{array}$ & $\begin{array}{l}\text { Lemon fruit comes } \\
\text { from cirebon farm with } \\
\text { harvest time at after 6 } \\
\text { months }\end{array}$ \\
\hline 2. & Toothpaste & $\begin{array}{l}\text { Calcium carbonate, sorbitol, } \\
\text { silica hydrate, sodium lauryl } \\
\text { sulfate, sodium } \\
\text { monofluorophospate, } \\
\text { fluoride, perlite, cellulose } \\
\text { gum, potassium citrate, } \\
\text { sodium silicate, sodium } \\
\text { saccharin, DMDM } \\
\text { hydnation, Cl 74160, Cl } \\
\text { 77891 }\end{array}$ & $\begin{array}{l}\text { Pepsodent whitening, Indonesia } \\
\text { Unilever }\end{array}$ \\
\hline 3. & $\begin{array}{l}\text { Tooth } \\
\text { brush }\end{array}$ & $\begin{array}{l}\text { Toothbrush with soft soft } \\
\text { bristles }\end{array}$ & Systema, Lion Japan \\
\hline phectro- & $\begin{array}{l}\text { Dental color measuring tool } \\
\text { photometer }\end{array}$ & $\begin{array}{l}\text { Vita Easyshade V, } \\
\text { USA }\end{array}$ \\
\hline
\end{tabular}

The lemon used, is from Cirebon farm with harvest time at after 6 months (Table I). Lemon fruit is washed and then squeezed. It produce about $40 \mathrm{ml}$ lemon water each fruit. Lemon water, dripping on toothpaste as much as 3 drops for each tooth brushing. Application of brushing teeth with drops of lemon fruit had been done for 3 weeks. It requires 42 drops each week ( 3 drops x 2 times brush $\mathrm{x} 7$ days $=42$ drops).

Toothpaste used in this study is a commercial toothpaste "Pepsodent Whitening" (Table I). Toothpaste smeared on toothbrush (Systema, Japan) along bristle. The total amount of brushing time for one week were 28 minutes ( 2 minutes $\times 2$ times $\times 7$ days $=28$ minutes). In the second week, the total amount of tooth brushing tooth were 56 minutes ( 2 minutes $\mathrm{x} 2$ times a day x 14 days $=56$ minutes). At third week, the total amount of tooth brushing were 84 minutes ( 2 minutes $\mathrm{x} 2$ times a day $\mathrm{x} 21$ days $=84$ minutes). All participant's teeth color change were measured for three weeks respectively. After that, the measurement color were taken and analyzed statistically.

\section{RESULTS}

This study show the color change of the right maxillary central incisor of using citrus lemon and whitening toothpaste during 3 weeks of tooth brushing. Measurement color change for three weeks were taken with the spectrophotometer and will get the value of $\Delta \mathrm{E}, \Delta \mathrm{L}, \Delta \mathrm{C}, \Delta \mathrm{H}$.

TABLE II. THE MEAN VALUE OF $\triangle \mathrm{E}$ RIGHT MAXILLARY CENTRAL INCISOR TEETH WITH CITRUS LIMON AND WHITENING TOOTHPASTE BRUSHING

\begin{tabular}{|c|c|c|c|c|}
\hline & Mean & SD & N & Sig \\
\hline$\Delta \mathrm{E} 1$ & +1.3 & 1.3 & 15 & 0.007 \\
\hline$\Delta \mathrm{E} 2$ & +1.2 & 1.3 & 15 & 0.021 \\
\hline$\Delta \mathrm{E} 3$ & +1.6 & 1.5 & 15 & 0.009 \\
\hline \multicolumn{4}{|c|}{$\Delta \mathrm{E} 1=\Delta \mathrm{E}$ first week, $\Delta \mathrm{E} 2=\Delta \mathrm{E}$ second week, $\Delta \mathrm{E} 3=\Delta \mathrm{E}$ third week } \\
$\mathrm{p}<0,05$ there is a significant difference
\end{tabular}

$\Delta \mathrm{E}$ shows the total number of color changes. The $\Delta \mathrm{E}$ value is derived from the difference of average value of $\mathrm{E}$ after the application, minus the value of $\mathrm{E}$ before the application. Table II, the value of $\Delta \mathrm{E} 1$ $(+1.4 \pm 1.3), \Delta \mathrm{E} 2(+1.2 \pm 1.3), \Delta \mathrm{E} 3(+1.6 \pm 1.5)$ show the (+) value, it indicates color change every week. The results of statistical analysis with repeatead anova post hoc bonferroni for 3 weeks, of value $\mathrm{AE}$ show significant changes $(\mathrm{p}<0.05)$.

TABLE III. THE MEAN VALUE OF $\triangle \mathrm{L}$ RIGHT MAXILLARY CENTRAL INCISOR TEETH WITH CITRUS LIMON AND WHITENING TOOTHPASTE BRUSHING

\begin{tabular}{|c|c|c|c|c|}
\hline & Mean & SD & N & Sig \\
\hline$\Delta \mathrm{L} 1$ & $+1,2$ & 1,8 & 15 & 0,129 \\
\hline$\Delta \mathrm{L} 2$ & $+0,3$ & 2,1 & 15 & 1.000 \\
\hline$\Delta \mathrm{L} 3$ & $+0,7$ & 2,0 & 15 & 1.000 \\
\hline \multicolumn{5}{|c|}{$\Delta \mathrm{L} 1=\Delta \mathrm{L}$ first week, $\Delta \mathrm{L} 2=\Delta \mathrm{L}$ second week,$\Delta \mathrm{L} 3=\Delta \mathrm{L}$ third week 3} \\
$\mathrm{p}<0,05$ there is a significant difference
\end{tabular}

$\Delta \mathrm{L}$ shows the number of the "value or lightness" color changes from white to black. The value of $\Delta \mathrm{L}$ is derived from the difference of average value of $\mathrm{L}$ after the application minus the value before the application. Table III shows the mean value of $\Delta \mathrm{L}$ of the right maxillary central incisor teeth. This study shows the mean value $\Delta \mathrm{L} 1(+1.2 \pm 1.8), \Delta \mathrm{L} 2(+0.580 \pm 2.1), \Delta \mathrm{L} 3$ $(+0.7 \pm 2.0)$. The positive $(+)$ sign indicates that the lightness of the teeth increase every week by using citrus lemon and Pepsodent whitening. The $\Delta \mathrm{L}$ statistical analysis results show no significant changes $(\mathrm{p}>0.05)$.

TABLE IV. THE MEAN VALUE OF $\triangle \mathrm{C}$ RIGHT MAXILLARY CENTRAL INCISOR TEETH WITH CITRUS LIMON AND WHITENING TOOTHPASTE BRUSHING

\begin{tabular}{|c|c|c|c|c|}
\hline & Mean & SD & $\mathbf{N}$ & Sig \\
\hline$\Delta \mathrm{C} 1$ & +1.0 & 1.3 & 15 & 0.059 \\
\hline$\Delta \mathrm{C} 2$ & +0.7 & 1.2 & 15 & 0.259 \\
\hline$\Delta \mathrm{C} 3$ & +1.1 & 1.8 & 15 & 0.187 \\
\hline
\end{tabular}

$\Delta \mathrm{C}$ shows the number of changes in the concentration degree of color purity, intensity or saturation. The value of $\Delta \mathrm{C}$ is derived from the difference of average value of $\mathrm{C}$ after the application, minus the value of $\mathrm{C}$ before the application. Table IV 
shows $\Delta \mathrm{C} 1(+1.0 \pm 1.3), \Delta \mathrm{C} 2(+0.7 \pm 1.2), \Delta \mathrm{C} 3(+1.1 \pm$ 1.8). Positive values (+) show the degree of color of the dental lightness saturation, increased. Statistical analysis by repeated anova for 3 weeks of $\Delta \mathrm{C}$ show no significant changes ( $p>0.05)$.

TABLE V. THE MEAN VALUE OF $\triangle H$ RIGHT MAXILLARY CENTRAL INCISOR TEETH WITH CITRUS LIMON AND WHITENING TOOTHPASTE BRUSHING

\begin{tabular}{|c|c|c|c|c|}
\hline & Mean & SD & N & Sig \\
\hline$\Delta \mathrm{H} 1$ & -0.7 & 0.9 & 15 & 0.082 \\
\hline$\Delta \mathrm{H} 2$ & -0.4 & 1.7 & 15 & 1.000 \\
\hline$\Delta \mathrm{H} 3$ & +0.2 & 1.9 & 15 & 1.000 \\
\hline \multicolumn{5}{|c|}{$\Delta \mathrm{H} 1=\Delta \mathrm{H}$ first week; $\Delta \mathrm{H} 2=\Delta \mathrm{H}$ second week; $\Delta \mathrm{H} 3=\Delta \mathrm{H}$ third week } \\
$\mathrm{p}<0,05$ there is a significant difference
\end{tabular}

$\Delta \mathrm{H}$ indicates the number of changes in the specific degree of chromatic colors from yellowish to reddish. The value of $\Delta \mathrm{H}$ is derived from the difference in average value of $\mathrm{H}$ after the application, minus the value of $\mathrm{H}$ before the application. Table $\mathrm{V}$ shows the mean value of $\Delta \mathrm{H}$ at right maxillary central incisor teeth with lemon and whitening toothpaste brushing for 3 weeks. This study shows that the value of $\Delta \mathrm{H} 1(-0.7 \pm$ $0.9), \Delta \mathrm{H} 2(-0.4 \pm 1.7), \Delta \mathrm{H} 3(0.2 \pm 1.9)$. The value of delta $\mathrm{H}$ appears increase every week. This indicate increasing of yellowish color of the teeth. Statistical analysis with repeated anova for 3 weeks show no significant differences of $\Delta \mathrm{H}$ value ( $\mathrm{p}>0.05)$.

\section{DISCUSSION}

The aim of this study is to know the effect of Citrus limon and whitening toothpaste o teeth color changes. This study was performed on right maxillary central incisor; because this tooth were the representative's teeth and will be seen first time when smile.

This study, use a spectrophotometer (Vita Easyshade V, USA) by the method of CIE L*a*b* and CIE L*C* H. Spectrophotometer calculate color parameters on the space $\mathrm{L}^{*}, \mathrm{a}^{*}, \mathrm{~b}^{*}$, based on the CIELAB system which is made by the Commission International de I'Eclairage or CIE in 1978. The CIELAB system discribe three-dimensional color perception. All colors confirmed on the three coordinate axes: $L^{*}, a^{*}, b^{*}$. The parameters $L^{*}, a^{*}$, and $b^{*}$, can be calculated from the total value of light reflection on objects that irradiation as $\mathrm{dE} * \mathrm{ab}$ [8].

VITA easyshade use sistem of $\mathrm{L}^{*} \mathrm{C} * \mathrm{~h}$ value to measure teeth color. " $\mathrm{L}$ " is the value that determines the color range from the value 0 (black) - 100 (white). The higher of the value of $\mathrm{L}$, the brighter the color. Meanwhile the lower of the value of L, the color will be darker. Chroma (C) is the degree of the saturation or intensity of the hue $(\mathrm{H})$. The higher the value of $\mathrm{C}$, the color get saturated. $\mathrm{H}$ is hue which is determines the degree of yellowish light to reddish. The higher of the value of hue, the more yellowish. While the lower of value of hue, the reddish increasingly appear. $\Delta \mathrm{E}, \Delta \mathrm{L}$, $\Delta \mathrm{C}, \Delta \mathrm{H}$ indicates the number of color change that occured $[9,10]$.

The results of this study; Tables II, III, IV, V show the changes of values of $\Delta \mathrm{E}, \Delta \mathrm{L}, \Delta \mathrm{C}, \Delta \mathrm{H}$ for 3 weeks.
The value of $\Delta \mathrm{E}$ (degree of total color change) increased for 3 weeks. This decrease of mean value of $\Delta \mathrm{E}$ for 3 weeks respectively indicates there is color change in the teeth because of lemon and whitening toothpaste use. Total of color change $\Delta \mathrm{E}$ is influence by $\Delta \mathrm{L}, \Delta \mathrm{C}$ dan $\Delta \mathrm{H}$. R.W. Pratiwi (2012) explain in his research that changes in the value of $\Delta \mathrm{E}$ is influenced by a decrease in $\Delta \mathrm{L}$ [11]. The $\Delta \mathrm{L}$ value shows that the value increased for three weeks (Table III). The increese of mean $\Delta \mathrm{L}$ indicate the brighter of the teeth lightness color.

In this study, value of $\Delta \mathrm{C}$ (degree of color density value or lightness) were increased. This indicate that the change in color of the enamel surface, it becomes brighter. Chroma is a term that describes the saturation, intensity, or the strength of hue, so it can be displayed along with hue. As an example, chroma enhancement on porcelain restorations can be improved by the addition of hue [12]. Value of $\Delta \mathrm{H}$ (degree of yellowishreddish) in this study increased, this indicates a change of degree chromatic colors, it appear yellowish.

The function of whitening toothpaste is to remove stains by mechanical or chemicals, to reduce the formation of plaque and abrade stains, to strengthen the teeth against dental caries, to clean and polish the tooth surface, to eliminate or reduce bad breath, to give a fresh feeling on mouth and maintain the health of the gingiva $[13,14]$.

According to the ADA (2001) whitening toothpastes contain abrasives, humectan, thickening, flavoring and foaming material. Abrasive able to remove debris and residual stain. Humectants to prevent water loss, thickening agents or binders formula to stabilize toothpaste and prevent separation of solid and liquid ingredient. A therapeutic agent consists of fluoride that able to reduce caries, potassium nitrate that is used for dentin hypersensitivity treatment, and triclosan or stannous fluoride that is able to reduce gingival inflammation. Another ingredient that is added is pirophosphat or zinc citrate that is able to prevent the formation of tartar and a variety of abrasives or enzymes that help whiten teeth [15].

Dental bleaching research using natural ingredients has been studied previously. According to Reksodiputro research (2005), fruit with acid content can whiten the color of teeth due to external discolouration. Fruit that has high acid properties, potentially become a strong oxidizer as well as hydrogen peroxide [16]. The reaction that occurs is an oxidation reaction in which electrons released by acid reacts with unsaturated bonds, it caused electron conjugation disruption and energy-absorbing change on organic molecules email. Disconnection of saturated bond will form a smaller organic molecules and the color of the teeth will be looked brighter [17].

Lemon (Citrus limon) is one of the natural ingredients that provide numerous benefits in the field of health. It can be use to cure toothache, stop gum bleeding and scent bad breath. In addition, a lemon can be used to whiten teeth, because the presence of malic 
acid. Malic acid is a group of carboxylic acids that have the ability to whiten teeth by oxidizing the tooth enamel surface. This substance can penetrate dentin and can release free oxygen on the double bond of organic and inorganic compounds in dentinal tubules [18]. Beside malic acid, lemon juice also contains citric acid 5\%, ascorbic acid (vitamin c), gluaric acid, and polyphenols that able to whiten teeth $[3,19]$. According to the reserach of Room (2012), the degree of the acid-base of the lemons are at $\mathrm{pH} 2-3$. This degree is highly acidic and is under critical $\mathrm{pH}$ email $(\mathrm{pH}$ 5.5). It results demineralization because the $\mathrm{pH}$ content of the lemons is at $2-3$, so it can make the teeth appear to be whiter [20].

The research in this study comformed by the opinion of Margareta (2012) who said that the lemon fruit can remove stains on the surface of teeth and make teeth look brighter. Our practical recipe for making teeth whiter is 3 drops of lemon for 2 weeks routine can make the teeth look whiter [3].

Based on the color measurement which is seen from the value of $\Delta \mathrm{E}, \Delta \mathrm{L}, \Delta \mathrm{C}$ and $\Delta \mathrm{H}$, we conclude that the use of citrus lemon and toothpaste whitening will make the color of teeth become brighter. Further research is needed on the duration and effects of Citrus limon and whitening toothpaste on tooth surfaces.

\section{REFERENCES}

[1] A. Jayakumar, H. Padmini, A. Haritha, Krishnanjanega, P. Reddy, "Role of dentifice in plaque removal: A clinical trial," Indian Journal of Dental Research, vol. 21(2), pp. 213, 2010.

[2] A. Meizarini, D. Rianti, "Bahan pemutih gigi dengan sertifikat ADA/ISO," Majalah Kedokteran Gigi Indonesia, vol. 38(2), pp.73-76, 2005.

[3] S. Margareta, 101 tips dan terapi alami agar gigi putih dan sehat. $1^{\text {st }}$ ed., Yogyakarta: Pustaka Cerdas, 2012. pp. 25.

[4] R.G. Craig, J.M. Powers, L. Ronald. "Restorative dental materials. $11^{\text {th }}$ ed., Missouri: Mosby Inc., 2002, pp. 206-212.

[5] W.J. O'Brien, Dental materials and their selection, $3^{\text {th }}$ ed., Quintessence Publishing Co. Inc., 2002, pp. 24.

[6] S.J. Chu, A. Devigus, A. Mielezko, Fundamental of color: Shade matching and communication in esthetic dentistry, Quintessence Publishing Co. Inc., 2004. pp. 34.

[7] N. Adrian, Penentuan warna gigi insisif sentral dan kaninus dengan spektrofotometer, Universitas Indonesia. 2012, pp. 20.

[8] D.L.D. Silva, C.T. Mattos, M.V.A. Araujo, A.C.O. Ruellas, "Color stability and fluorescence of different orthodontic esthetic archwires," Angle Orthodontist, vol. 83(1), pp. 127-132, 2013.

[9] K.J. Anusavice, C. Shen, H.R. Rawls, Philips' Science of dental material, $12^{\text {th }}$ ed., St Louis: Elsavier Inc., 2013, pp. 34-37.

[10] V.K. Sikri. "Color: Implications in dentistry," JCD., vol. 13(4), pp. 249-255, 2010.

[11] R.W. Pratiwi, Pengaruh lama perendaman terhadap perubahan warna resin komposit nanohibrida akibat konsumsi minuman soda aneka warna dan rasa, Malang: Fakultas Kedokteran Gigi Universites Brawijaya, 2014.

[12] Aschheim, W. Kenneth, B.G. Dale, "Esthetic dentistry a clinical approach to technique and materials," $2^{\text {nd }}$ ed., Mosby Co., 2001, pp. 4.

[13] A.M. Edwina, S.J.B. Kidd, Dasar-dasar karies penyakit dan penanggulangannya, EGC, 1991, pp. 140.

[14] S.S. Inne, M.H. Arlette, "Gambaran efek pasta gigi yang mengandung herbal terhadap penurunan indeks plak," Kedokteran Unpad., 2006, pp. 2-4.

[15] ADA, "Whitening toothpastes," J. Am. Dent. Assoc., vol. 132(8), pp. 1146-1147, 2001.
[16] M. Suleiman, "An overview of bleaching techniques: 2. Night guard vital bleaching and non-vital bleaching," Dent. Update, vol. 32, pp. 39-46, 2005.

[17] R.E. Goldstein, D.A. Garber DA, Complete dental bleaching, Quintessence Publishing Co. Inc., 2005, pp. 33.

[18] U. Rudhrappa. (2015, May 4) Lemon nutrition fact. Available: <http://www.nutrition-and-you.com/lemon.html $>$.

[19] K. Patil. (2015, May 4) Health Benefits of lemon. Available: <http://www.organicfacts.net/health-benefits/fruit/healthbenefits-of lemon.html>.

[20] M. Anim. (2015, May 4) Limau lemon. Available: <http://anim hosnan.blogspot.com/2011/04/limau-lemon.html. . 